\title{
Obituary
}

\section{In Memoriam Aleksandr L. Makovskii}

Ferdinand Feldbrugge

Professor Emeritus, University of Leiden, Leiden, The Netherlands f2hfeldbrugge@hetnet.nl

\section{William B. Simons}

Professor Emeritus of East European Law, University of Leiden, Leiden, The Netherlands

wbsimons@gmail.com

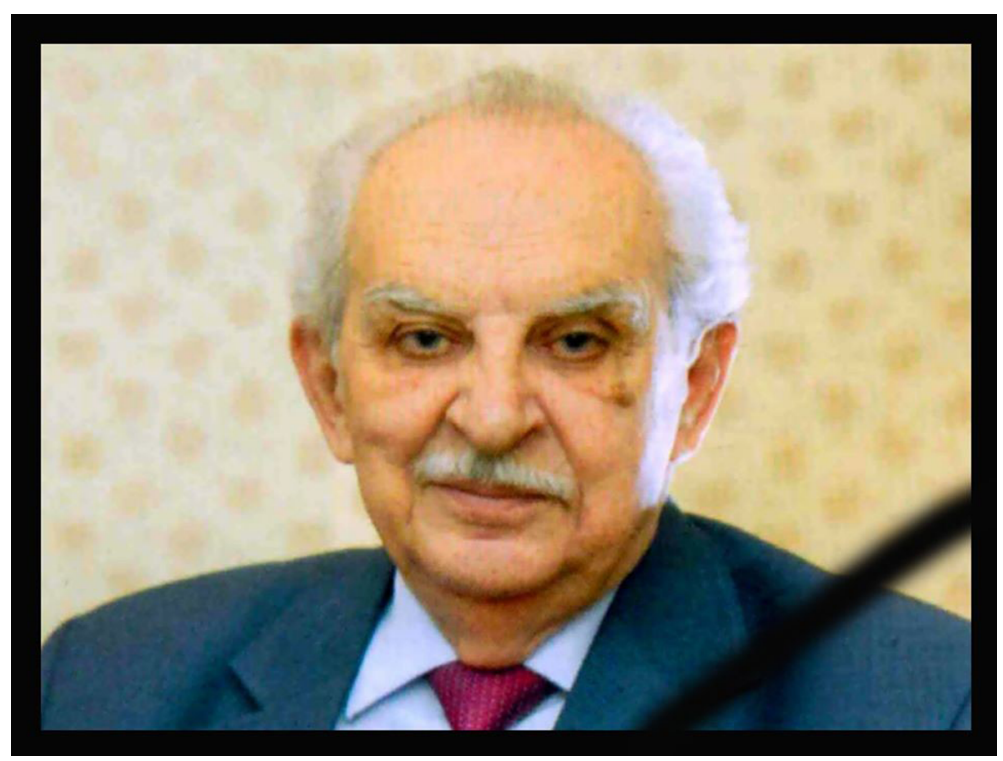


Aleksandr L'vovich Makovskii was born in Leningrad in 1930 in a family which gave Russia a number of renowned painters, art historians, writers, and academics. As a boy, he was among those who survived the long siege of Leningrad during World War II. Makovskii then studied law at the Leningrad State University graduating, with distinction, in 1953. There, a young O.S. Ioffe - later to become, arguably, the greatest civilist of the Soviet era - had been one of his teachers. In that same year, Makovskii started his graduate studies in law at the All-Union Institute of Legal Science (AUILS) in Moscow, becoming a member of its academic staff in 1956. It marked the beginning of his scholarly career in the two fields which would become the main spheres of his professional interests: civil law and private international law.

He earned a candidate-of-science graduate degree in 1959. His thesis dealt with the legal regime governing the carriage of goods by Soviet ships, and his supervisor was a remarkable AUILS faculty member: Professor Ekaterina Abramovna Fleishits. ${ }^{1}$ Makovskii received his doctorate-in-law - on problems of private international law and the law of the sea - in 1984 from the All-Union Scientific-Research Institute for Soviet Legislation (AUSRISL) also in Moscow.

In the late 196os, Makovskii became head of the legal department at a Moscow maritime-transport research institute - remaining there until 1980. During the last five years of this period, he was also an advisor to the Soviet delegation at the Third UN Law of the Sea Conference. The position was, for him, unexpected (as he would describe it in 2012) but very close to his love for civil law and private international law. It may have come about - as he later mused - because of his participation in drafting a number of International Maritime Organization conventions beginning in the late 196os. In this stage of his career, he also was one of the founders of the Association of Maritime Law in Russia.

In the early 1980s, Makovskii moved to AUSRISL and, in 1988, became professor of law. From 1981 until 1992, he was chief of the Institute's section dealing with legislation on international relations; later, head of its department of private international law. (By then, AUSRISL had been renamed the Institute of Legislation and Comparative Legal Studies and, since 1993, has been attached to the Russian Government.)

However, it was his decades-long association with the Research Center for Private Law (attached to the Office of the Russian President) which formed the pinnacle of his career. The Center - suggested by one of the most vocal

1 She reportedly was the first female practicing attorney in Imperial Russia and the first woman to be awarded a doctorate-in-law in Soviet Russia. 
proponents of the re-birth of private law in Russia, Professor Sergei Sergeevich Alekseev - was established by RF Presidential order in December $1991,{ }^{2}$ and Makovskii was there from its very beginning.

First, he was a Deputy to the Chairman of the Center's board; becoming the First Deputy Chairman in 1997. In the mid-2010's, he took on the role of the Center's Research Director for several years. The Center's remarkable scientific collective of scholars and associates was formed, in large part, owing to Makovskii's overwhelming enthusiasm for the re-birth of private law.

Along with several other leading lights of Russian civil law, Makovskii was also enthusiastic about promoting top educational opportunities in the field of private law for Russia's 'brightest and best'. This work included acting as co-founder, in 1995, of the graduate-level Russian School of Private Law (also established under a RF Presidential order and located - as is the Research Center - in Moscow and Ekaterinburg) plus serving a term as the Moscow School's Rector.

His influence upon young Russian lawyers also encompassed a moral element of which Makovskii himself was a prime example; serving science and the ideals of law as was the case among many of the Russian intelligentsia. He also was an accomplished orator as well as writer - distinguished by the way in which he brought words to life; the grace with which he expressed his ideas.

He also was a member of advisory boards and counsellor to the three highest courts in the Russian Federation, an arbitrator in Russia's two oldest international, commercial arbitral tribunals, and a member of the Russian International Law Association. A number of honors were bestowed upon Professor Makovskii in recognition of his many achievements. These included four Russian Government medals and awards from the Russian legal community and foreign countries.

When the political and economic structure of the Soviet Union began to disintegrate in the beginning of the 'nineties of the last century, the first steps towards a transition to a market economy began to be taken. It very soon became clear that such a transition required, first of all, the introduction of a legal system facilitating economic growth. After several quickly assembled ad hoc laws - generally causing even more confusion - it dawned on those in the Russian government responsible for legal reform that a comprehensive reconstruction of the entire system of private law would be the only sensible response to the problem. Translated into practical terms, this meant drafting an entirely new Civil Code. The outlines of such an endeavor were sketched

2 Under a 2013 RF Presidential Edict, the Center is now named in honor of S.S. Alekseev. 
by eminent lawyers, close to the government, such as S.S. Alekseev and V.F. Iakovlev. The actual task of drafting was entrusted to a team - under the umbrella of the Research Center in Moscow - with Makovskii as chairman.

It was a task of staggering complexity and enormous size. Many basic concepts - inherited from Soviet times such as property, legal persons, and contracts - had to be redesigned for a completely different content. Numerous legal institutions not required by the Soviet legal system had to be defined and assigned a place. And this work had to be done in an incredibly short time, as the whole economic reform could not start - with any meaningful chance of success - without a proper legal basis. Moreover, it had to be done by a group of lawyers who themselves had little experience in working with such a new system.

We (the authors of this obituary) were fortunate in having been present at many sessions of the Civil Code's working group - led by Makovskii in Russia as well as in the EU and North America - and believe that his leadership was perhaps the most important factor in the success of the entire operation. His boundless energy, his unshakable belief in the decisive value of the project, his great legal intelligence, his ability to inspire his colleagues in their almost superhuman effort; all of these helped the team to complete the first part of the Civil Code - devoted to civil-law principles, the law of property, and the general part of the law of obligations - in 1994, so that it could enter into force on 1 January 1995. But there was no relaxation, then, as the Code's next three parts were completed successively in 1995 (specific obligations), 2001 (the law of succession), and 2006 (intellectual property). Along with these four constituent parts of the Civil Code (in accordance with the existing tradition, family and labor law were regulated in separate codes), several teams of experts consisting of members of the Civil Code drafting team and a few others produced commentaries on the Civil Code, all under Makovskii's general editorship.

The drafting of each part of the Russian Civil Code was followed by the adoption process, which involved shepherding the text through the different stages of the parliamentary procedures. Passage of the Code's first part had, in particular, been marked by fierce opposition from the Communist Party's parliamentary fraction. Professor Makovskii was one of the principal agents in securing parliamentary approval for all four parts - the ultimate success owing much to his diplomatic skills, his indomitable vision, and the tenacity of his purpose.

During the Soviet era, each of the fifteen Union Republics had its own codes of law, including a civil code. But the drafting work for the bases of the Republics' codes - e.g., the Fundamental Principles of Civil Legislation of the USSR (FPCL) for their civil codes - was, in fact, done centrally in Moscow. The 
result was that the texts of all fifteen codes of law from the 196os were very similar - giving the uss b basically a uniform legal system. ${ }^{3}$

In the post-Soviet era, he - along with many others - realized that any diversification of civil law would be detrimental; first of all, to the new Russian Federation but, also, to all the newly independent states of the former Soviet Union.

He vociferously opposed the suggestions of some to allow the more than 80 Subjects of the Russian Federation (provinces, regions, etc.) to promulgate separate 'trade codes' only for their areas. His firm conviction was that the unification of civil law - including commercial (or economic/trade) law - was critical for the Federation's further economic development; for institutionalizing, for example, the principles of good faith, reasonableness, and fairness in civil-law relationships for the whole of Russian society. However, in promoting the achievement of these goals across the breadth of the former Soviet Union, he also worked tirelessly but realistically to achieve the harmonization - rather than unification - of civil law through initiatives to draft a Model Civil Code and a Model Law on Limited Liability Companies for the countries of the Commonwealth of Independent States (CIS).

These initiatives, ultimately, were taken over by the Assembly of the CIS, and Makovskii became the chairman of the cis working group for drafting such a Code and Model Law (as well as Council Chairman of the CIs' ScientificConsultative Center for Private Law).

As work on the Russian Civil Code was already progressing well at that time, the Russian draft was a logical source for much of the text required in preparing the Model Code. This multi-year effort was marked by the participation of other leading civil-law specialists from almost all of the republics - a number of whom had already collaborated with Makovskii in crafting the earlier FPCLS. The outcome was that all of the newly independent states (with the exception of Georgia, which adopted a Civil Code drafted with the aid of a German expert) ended up with similar civil codes of a level which some of them would never have been able to attain - in a short period of time - without a model-code approach.

Professor Makovskii's leadership of civil-law reform in Russia and other states of the former Soviet Union was also grounded in his knowledge of legal history and the value of comparative law in modernizing private law in the

3 Makovskii had been involved - along, notably, with Professors Fleishits and Ioffe - in drafting the 1961 FPCL and the 1964 Russian Civil Code; also advising the draftspersons of the other fourteen Union-Republic civil codes. In addition, Makovskii was in the working groups which drafted the USSR Merchant Shipping Code (1968) and the 1991 FPCL (although the latter never officially entered into force owing to the breakup of the UsSR). 
region. One of his favorite thinkers was Iosif Alekseevich Pokrovskii (who had also exercised a major influence upon Fleishits), and Makovskii's intellectual reach extended not only to the FPCL and the Republic codes from the 196os but, also, to the civil-code-like draft 1905 Imperial Grazhdanskoe Ulozhenie. Furthermore, Makovskii and his working-group colleagues often took inspiration from civil- and commercial-law developments in European states and North America in drafting the Russian and Model cis Civil Codes.

For lawyers and others in Russia and abroad, the Civil Code of the Russian Federation will remain as a monument for that remarkable man, Aleksandr L'vovich Makovskii, for many years to come. His memory will be cherished with sympathy and gratitude by all those who had the privilege of having known him and worked with him. 